\title{
The Little Prince in Bookstagram in the Context of the Culture Industry: From Asteroid B-612 to Social Media Planet
}

\author{
Metin IŞIK ${ }^{1} \&$ Lütfiye YAŞAR ${ }^{2}$
}

\begin{abstract}
With the Internet taking place in the usual flow of life, various variations of communication forms have been derived. In the new media tools, the individual produces content in this medium through the prosumer quality either through his/her own identity or imaginary characters. The influence of the culture industry is growing day by day in this virtual world where prosumer share and commodify art and literature. Antoine de Saint-Exupéry's novel hero, The Little Prince, takes place in this digital world, which is taken step by step by the culture industry, with Instagram accounts. The research is important in addressing the cultural or artistic activities of prosumers in the context of the social media and culture industry. How The Little Prince Hub page commodified a literary product with a bookstagram identity was examined by discourse analysis method. As a result of the research, it was determined that a simple, positive and active constructive language was used in the sharing of the page.
\end{abstract}

Key Words: Culture Industry, Instagram, Bookstagram, Little Prince, Social Media

Kültür Endüstrisi Bağlamında Bookstagramdaki Küçük Prens: Asteroid B-612'den Sosyal Medya Gezegenine

$\ddot{O} z$

İnternetin olağan hayat akışı içerisinde yer almasıyla iletişim formlarının çeșitli varyasyonları türemiştir. Yeni medya araçlarında birey, üre-tüketici vasfi ile ister öz kimliği isterse de hayali karakterler vasıtasıyla bu mecrada içerik üretmektedir. Üre-tüketicilerin sanat ve edebiyat eserlerini paylaşıp metalaştırdığı bu sanal dünyada kültür endüstrisinin etkisi her geçen gün daha da büyümektedir. Kültür endüstrisinin adım adım ele geçirdiği bu dijital dünyada Antoine de Saint-Exupéry'in Küçük Prens isimli roman kahramanı da İnstagram hesaplarryla yerini almaktadır. Araştırma sosyal medya ve kültür endüstrisi bağlamında prosumerların kültürel veya sanatsal faaliyetlerini ele alması bakımından önem arz etmektedir. Bu çalışmada The Little Prince Hub sayfasının bookstagram kimliğiyle bir edebiyat ürününü nasıl metalaştırdığı söylem analizi yöntemiyle incelenmiştir. Araştırma sonucunda sayfanın paylaşımlarında basit, olumlu ve aktif yapıda cümle yapılarında yapıcı bir dil kullanıldığı tespit edilmiştir.

Anahtar Kelimeler: Kültür endüstrisi, İnstagram, Bookstagram, Küçük Prens, Sosyal Medya

Atıf İçin / Please Cite As:

Işık, M. \& Yaşar, L. (2021). The Little Prince in bookstagram in the context of the culture 1ndustry: From Asteroid B-612 to social media planet. Manas Sosyal Arastirmalar Dergisi, 10(2), 1199-1213.

\footnotetext{
${ }^{1}$ Prof. Dr. - Sakarya University, Faculty of Communication, imetin@sakarya.edu.tr

(iD) ORCID: 0000-0001-5984-0328

2 Sakarya University, Institute of Social Sciences, lutfiye.yasar1@ogr.sakarya.edu.tr

(iD ORCID: 0000-0001-9008-6415
} 


\section{Introduction}

It can be said that the concept of popular culture and mass culture started to emerge with the same characteristics as economic activities since the last quarter of the 18th century (Koluaç1k, 2017, p. 137). Critical Theory theorists use the concept of popular culture and mass culture, which are qualitatively similar in the "Culture Industry" textiles, and they decide to use the concept of the culture industry based on the judgment that the culture products have been industrialized as commodities (Y1lmaz, 2018, p. 454; Ayaz, 2016, p. 126). Not the masses in the notion of the culture industry where Adorno and Horkheimer discussed the cultural codes transferred from generation to generation with historical and social evolution and their reflection on the modern life, individuals can be said to be in the foreground (Adorno and Rabinbach, 1975, p. 12). According to Adorno, mass is the ideology of the culture industry rather than the criterion (2020, p. 110).

According to Assoun (2014, p. 28), although Frankfurt School is a historical and cultural theory, it can be interpreted as an intervention about applying the school's goal. It can be stated that the maturation of the culture industry theory within the understanding of the philosophical tradition of the school stemmed from the historical philosophy of the Frankfurt School (Odabaş, 2018, p. 219; Assoun, 2014, p. 123).

Among the twentieth century thinkers, Marcuse, Benjamin, Horkheimer and Adorno argued that the concept of culture turned into a commodity after it entered the monopoly of capitalism. With the commodification, the culture industry changes the existing objects as cost so that the current thought begins to be accepted (Scott, \& Celia, 2007, p. 12; Cook, 1996, p. 86.) With this in mind, culture can leave a trace of uniformity in everything (in all media organs). The media does not have to evaluate their production with an artistic perspective. They are aware of the sameness of what they produce and can place it as a system of thought (Adorno, 2020, p. 47-48). Ultimately, it is the subject of research that culture has ceased to be produced by the masses and how culture has been dominated by the entertainment industry. These studies of Frankfurt School theorists regarding social change and commodification of culture are considered as important publications of the institute (Jessop, 2016, p. 414; Koluaçık, 2017, p. 137).

Adorno and Horkheimer argue that culture exists in the "Dialectic of Enlightenment" with practices that cannot be exchange and can be change (Grant, 2013, p. 4). Adorno offers the opportunity to see that the behavior of individuals and communities has changed with the culture industry. He also underlines that they are similar to each other. In this period, which covers the first quarter of the 21 st century, the widespread use of mass media, especially the internet, in the quantitative increase of cultural and artistic works, is of great importance in spreading the impact of the culture industry (Doğan, 2015, p. 137; Van Dijck, 2013, p. 39). It can be said that the result of the disappearance of the borders in the world with the mass media and the fact that even the most distant person, which is a necessity of our age, is constructing a new culture through the media of culture industry.

It can be said that the Internet, which is one of the modern communication methods, differs from the classical production tools as it provides the content producer and content consumer opportunity to its users. The notion of prosumer, the relationship between the producer and the consumer has become ambiguous with the participation of the consumer in the production process (Duman, \& Özdoyuran, 2018, p. 82). The system where the Web 2.0 user can produce content and also manage it is called userderived content. User-derived content allows to produce content in different variations from textiles to photography, video or podcasts (Filibeli, 2018, p. 451). All these web 2.0 services can contribute to the culture industry by individually serializing the production or consumption of artistic or cultural content to the consumer who produces content in each social media network.

Assoun associates the of a work of art in the modern age with the mass culture loss of the aura (2014, p. 133). The numerical superiority of popular works of art can obscure the access to the essence of the work. Within the scope of the research, the results of blending literary art products with cinema will be evaluated as leisure entertainment in social media fields. Sharing on the Instagram pages of the novel "The Little Prince", which is discussed whether the target audience is children or adults, is the subject of the study. It can be said that these Instagram shares are removed from the original form of the work and turned it into a product that is used to create virtual identity in new media environments. In addition, as the sharing of the work increases, the proposition that the product increases its popularity is taken as basis. The account determined for discourse analysis within the scope of the research is "The Little Prince 
Hub". Active sharing, high number of followers and quotes from the Little Prince novel are decisive factors in the selection of the account. The fan page "The Little Prince Hub" is important as it is among the first pages to be opened. The analysis covers between 1-30 June 2020. Research is important in terms of revealing how literature products commodify in social media environments and being among the first studies in the literature.

\section{The Commodification of Art in the Culture Industry}

In " Dialectic of Enlightenment ", Adorno and Horkheimer clearly reveal their views on art, and according to them, a work of art is stripped of its reality, creating its own secret space. Special laws are applied in this area (Adorno, \& Horkheimer, 2010, p. 38). According to Adorno, although art is autonomous, it should always be able to maintain its innovation, which is beyond its time and not regarded as ordinary (Ümer, 2016, p. 177). In short, the work of art must be able to accommodate essentially time and timelessness (Hellings, 2014, p. 71).

According to Adorno, the notion of culture industry cannot properly understand the accompanying of art, even if individuals with a desire for commodity tend to art. At this point, the tools that a work uses when it turns into a commodity are taken into consideration. He expresses that the influence of the culture industry is increased with this warm contact with art. In short, he argues that the culture industry turns art from self and essence into consumption goods (Romero, 2011, p. 2). According to Adorno, detachment from its core has both an imperative and a reason in the context of the cultural industry (Romero, 2018, p. 4-5). While expressing the authenticity of art with aura in the traditional societies, the reproducibility of works of art with modernization can damage the singularity and uniqueness of the work (Moore, 2012, p. 76-77). The reproduction of art, which is seen as a mirror of social feelings, is thought to have lost its aura, naturalness and purpose, with the influence of the culture industry (Yurdigül, Yurdigül, \& Batur, 2016, p. 106; Sevim, 2010, p. 510-511; Bottomore, 2016, p. 23). Art, which has lost its purpose, can move towards a commodity that can be measured financially by moving its existence in the popular culture society out of the satisfaction area obtained free of charge (Kalkan ve Altınkurt, 2012, p. 132). These concepts can be positioned in different axes when evaluating art and society in the perspective of Frankfurt School (Fenercioğlu, 2012, p. 6). This opposition promises happiness along with the opposite of the barbarism that continues in civilization (Jessop, 2016, p. 414-415; Assoun, 2014, p. 129; Hellings, 2014, p. 72). The culture industry can form an artistic form, which does not contain any negative elements in its form, and is managed by a planned integrated process. Horkheimer and Adorno consider civilization and barbarism as the output of the same historical process and interpret it as the essence of modern art (Swingewood, 1996, p. 37).

According to Adorno, art work in the culture industry does not commodize but if it is produced for the market, it turns into a commodity. The imitation in modern works of art is not as convincing as the homeopathic treatment methods that raise negative criticism. But homeopathic therapy can activate immunity by enhancing belief in treatment (Finlayson, 2014, p. 1162). This ideology, which strives to manipulate the masses, wants to establish a control mechanism. In addition, although it seems contradictory with the society, it has this style of thought at its core (Stone, 2014, p. 21; Dellaloğlu, 2018, p. 108-109). According to Han (2019, p. 11), due to its contradictory nature, the negative dialectic that contains its antidote can thus become immune.

According to Adorno, the sign of the detachment of the art from its autonomy is that it can be positioned in consumer commodities. It can be related to the originality of the work that was created by feeling the conceptuality and the cost attributed to art, and this is a common theory. This relationship with the culture industry cannot be controlled. False behaviors are displayed against artistic works due to the imperative of screening the sensibility and selectivity of the work (Finlayson, 2015, p. 393). The culture industry destroys the autonomy of art, allowing it to be commodified (Grant, 2013, p. 4; Boratav, \& Gürdal, 2016, p. 99). As a result of the commodification of art, it can be said that the aesthetic principles that make up the understanding of creativity and beauty in art have lost their power. In this environment where artistic aesthetic principles are destroyed, it is not possible to evaluate the work based on its pleasant perception (Adorno, \& Horkheimer, 2000, p. 103). In the industrial age, the artistic aesthetic system that will produce " something " is formed, not the existence of each object (Renkçi, 2014, p. 65). 


\section{Commodified Content in New Media and Identity}

While all the cultures available on earth can gain meaning and be unique with the people in their geography and their ceremonies, they can bring them together regardless of the area of the town with the new media ( Sawyer, \& Chen, 2012, p. 151). The integration of new media and globalization can only break the shell of the concept of cultural identity by moving out of the traditional time and place. In our age, with the technology that human beings consume intensely and the culture transferred to the virtual universe, it creates changes in the identity and consumption behaviors of individuals. With this change, individual can focus on objects that explain their essence in society.

Technology is said to be one of the most popular culture commodities in the current time frame. Technology, which attracts the attention of mankind, interferes with its understanding of action and truth, as well as its nature, and can create a consumer face by creating an artificial life with the ideology of global culture. In short, identity can be created by virtually through image (Anık, \& Soncu, 2011, p. 63; Nar, 2015, p. 950-951).

While the digital environment calls its users to a specific culture and identity, on the other hand, it can provide the ground for socialization by rediscovering the selfies of its users with its interactive infrastructure. Although this community, which is formed with a global network structure, is anonymous, people can build virtual identity in this medium. The elastic structure of the virtual environments can allow the sudden generation of highly differential identities, to be consumed immediately and finally to set up new identities (Şahoğlu, 2019, p. 178). The individual can access cultural elements in different scales, from pronunciation to fashion trends, from artistic activities to media use relations, with the identity he / she has formulated in the way his/her wants (Güzel, 2006, p. 6-7). Thus, the earth flows through the filter of the culture industry (Adorno, \& Horkheimer, 2000, p. 99).

The individual creates an image with the users through video, photo or text messages published in his/her social media profile. In addition to exhibiting his/her own inner world in virtual environments, he/she can share his/her perspective and his/her private life. According to Sandvig (2015, p. 2), it is possible to say that the cultural industry has gained a new form with social media entering our lives. Actions in social media can contribute to the culture industry ideology facility. Sometimes the feeling of being familiar is at the core of these socializing areas becoming trends and gaining value. The elements that make the profiles with high number of followers appreciable can consist of numbers, symbols and images (Güzel, 2016, p. 87).

Since Web 2.0 includes an interactive infrastructure service, media users can combine consumer and producer identity in this environment. Social media users who combine this identity are called prosumer (Lankauskaite, \& Liubiniene, 2018, p. 54). Prosumer in social media can be realized in cooperation with producer and consumer in new media with the integration of production and consumption. With the progress made in Web 2.0, a quantitative increase in the use of social media can be observed (Zhang, 2017 , p. 2). According to the ideology of the culture industry, while prosumer presents a value to commodify in new media tools, it is not attached to the time and location constraints due to the anatomy of this environment. Based on the viewer commodity principle, social media users can gain tangible benefits through the abstract meta. As a result, with the elimination of existing restrictions in working and commodity production through the internet network of the globe, wherever internet access is available, it can turn into a commodity production facility (Duman, \& Özdoyuran, 2018, p. 96).

\section{Methodology}

The Little Prince, written by French writer Antoine de Saint-Exupéry, is on the most read books list. The Little Prince, published in 1943, criticizes the lives of adults through the eyes of a blue-eyed blonde boy in more than 250 languages.

The main purpose of the research is to reveal the relationship of virtual environments that are in close contact with the culture industry and to explain the factors that help these environments to grow popular culture. The study is important in terms of handling the cultural or artistic activities of prosumers in the context of social media and culture industry. The universe of the study conducted with the discourse analysis method is Instagram, and the sample is the "The Little Prince Hub" page.

There are many domestic and foreign accounts opened in the name of the Little Prince in Instagram, which is one of the social media tools. There are fan pages named "Little Prince", "The Little Prince BB612", "Little Prince Lover88", " Little Prince World", "The Little Prince Journey", "The Little Prince 
Everywhere" and "The Little Prince Hub". The account determined for discourse analysis within the scope of the research is "The Little Prince Hub". In the selection of the account, it includes active sharing, high number of followers and quotes from the novel Little Prince. It is also important to be among the first fan pages opened. The analysis covers between 1-30 June 2020. In memory of Antoine de SaintExupéry, who was born on June 29, 1900, the posts between 1-30 June 2020 will be examined.

\section{The Little Prince in Instagram: Discourse Analysis of Van Dijk}

The research was carried out with the critical discourse analysis method of Van Dijk. The technique used by Teun A. Van Dijk for the intellectual analysis of the government in written news was used to explain the analysis of the relationship between macro and micro structures that make up the discourse within the scope of the study. The discourse language was examined in line with the one-month sharings of the "The Little Prince Hub" page.

\section{Discourse Analysis}

The discourse, which is considered as notion, can be expressed with the characteristic symbols of the language, which is the backbone of the communication, with the braid of sociocultural and intellectual relations (Berg, \& Lune, 2019, p. 396). Discourse is shaped in social context and the purpose of discourse analysis is not to perform an ideology expertise. It is also to correlate discourse patterns with the intellectual structures in the form of a system (Van Dijk, 1988, p.19; Van Dijk, 1985, p. 143). It can be said that the use of content analysis method is a pioneer in the discourse analysis in the media textiles. The first discourse analysis studies in the literature emerged in the 1960's. It can be considered as an interdisciplinary field of study that blends semantics, folklore and linguistics in text and dialogue (Solak, 2011, p. 3; Van Dijk, 1995a, p. 17). According to Fairclough (2013, p. 357), discourse analysis creates a dialogue by drawing a method of its own as more than the collaboration of interdisciplinary studies related to research on social transformation. Critical discourse analysis, which tries to explain the construction in the media passage, discusses how the social structure behind the discourse of the media organs has evolved into linguistic speculation (Solak, 2011, p. 3). In critical discourse analysis, authority, power, value and identity can be evaluated as the effects of ideological products (Ulinnuha, 2013, p. 262-263).

According to Van Dijk, text analysis can be handled under two titles as macro structure and micro structure. Thematic and schematic elements are examined in macro structure. The headline, spot and photograph of the news are analyzed in a thematic structure. In the schematic structure, the background story of the main event and the evaluations of the parties in the news are gathered under two subtitles as comments and status. In the microstructure title, it is primarily syntactically examined in terms of causality and rhetoric between strings (Bayram, 2016, p. 1422; Destructed, 2020, p. 55).

\section{Findings}

Within the scope of the research, 11 shares of the "The Little Prince Hub" page between 1-30 June 2020 were analyzed according to the critical discourse analysis method. The shares were examined in two phases in accordance with the macro and micro structure. In macro structure, there are analysis of thematic and schematic elements, while in micro structure there is rhetorical analysis with syntactic and causality relation as secondary title. (Van Dijk, 1995b, p. 384-386). The contents are shown as photos and tables and then analyzed according to their macro and micro structures.

\section{Example 1: 06.06.2020 Dated Post}

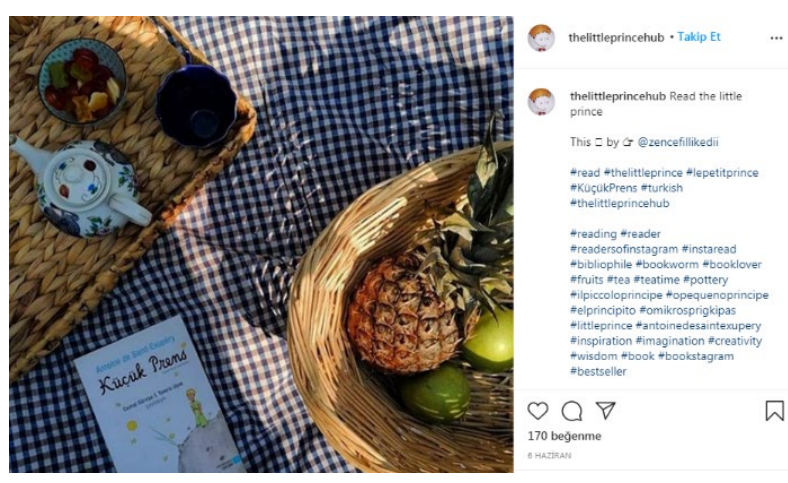


Table 1. 06.06.2020 Findings of the Interaction Rates of the Content of the Dated Post

\begin{tabular}{ll}
\hline Likes & 170 \\
\hline Interpretation & 19 \\
\hline Response to the content & 1 \\
\hline Content & Read the little prince \\
\hline Tag & \#read, \#thelittleprince, \#lepetitprince, \#küçükprens, \#turkhis, \#thelittleprincehub, \\
& \#bookworm, \#tea, \#furits, \#teatime \\
\hline
\end{tabular}

Micro Structure: In the post dated June 6, there are no metaphors used in the basic sense of the words. There is no causal relationship within the active and simple sentence structure in the one-sentence "Read the Little Prince" sharing.

Macro Structure: In the photo, there are fruits in a wicker basket and snack products on the tea tray. A message is given in relation to the text that reading action can be performed without time or space constraints. When the schematic structure of the sharing is examined, a positive, encouraging language is used. 18 comments were made on this post. One-page comment, the page manager wrote "I like this" in response to the comments of his followers.

\section{Example 2. 07.06.2020 Dated Post}

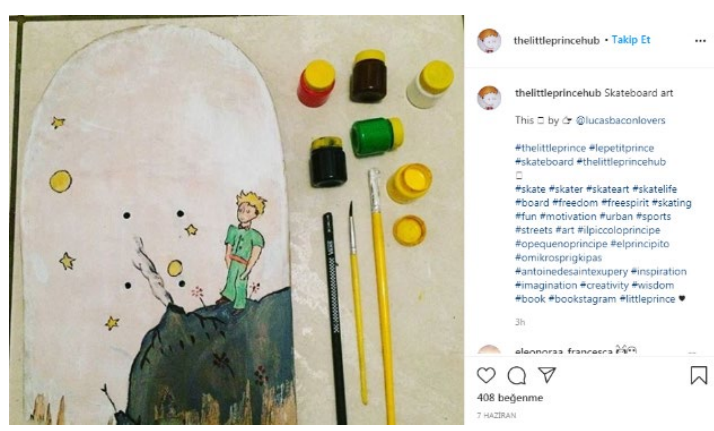

Table 2. 07.06.2020 Findings of the Interaction Rates of the Content of the Dated Post

\begin{tabular}{ll}
\hline Likes & 408 \\
\hline Interpretation & 6 \\
\hline Response to the content & 2 \\
\hline Content & Skateboard Art \\
\hline Tag & \#thelittleprince, \#lepetitprince, \#skateboard, \#thelittleprincehub, \#skating, \#art, \#fun \\
\hline
\end{tabular}

Micro Structure: In the content dated June 7, the words are used in their basic terms and no metaphor findings are encountered. 'Stateboard Art' 'Causality relationship cannot be interpreted because it is a simple sentence.

Macro Structure: The planet figure in the novel 'Little Prince' is depicted on a broken piece of skateboard. There are the details of the stars and volcanic mountain on the planet of the Little Prince. On the side of the skateboard part are paints and brushes used in painting. Since skateboarding symbolizes freedom, an allegorical expression is used in this sharing.

There is no discourse in the message that will marginalize and lead to polarization. A total of 6 comments were made to the content, 2 of which were the responses of the page manager, with the words of thanks and love to his/her followers.

\section{Example 3. 08.06.2020 Dated Post}

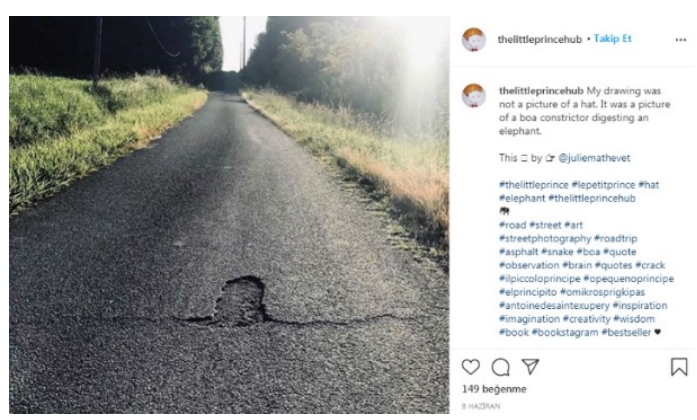


Table 3. 08.06.2020 Findings of the Interaction Rates of the Content of the Dated Post

\begin{tabular}{ll}
\hline Likes & 149 \\
\hline Interpretation & 6 \\
\hline Response to the content & 1 \\
\hline Content & My drawing was not a picture of a hat. It was a picture of a boa consrictor digesting an elephant. \\
\hline Tag & \#thelittleprince, \#lepetitprince, \#hat \#elephant \#thelittleprincehub, \#road, \#art, \#snake, \#boa \\
\hline
\end{tabular}

Micro Structure: In the message dated June 8, the words are used with basic meaning. Metaphor findings are not found. "My drawing was not a picture of a hat. It was a a picture of boa constrictor digesting an elephant. In the description, simple sentence was used in the active sentence structure." It consists of two sentences and a simple sentence is used in the active sentence structure. A causality relationship was tried to be established about the meaning of the picture between the two sentences.

Macro Structure: The photo shows cracks in the empty road. There is a reference and use of metaphors to those moments when the pilot in the Little Prince novel describes his painting experience but no one understands his painting. 6 comments were made to the content, which has a positive language use. One of these comments was answered by the page manager.

\section{Example 4. 10.06.2020 Dated Post}
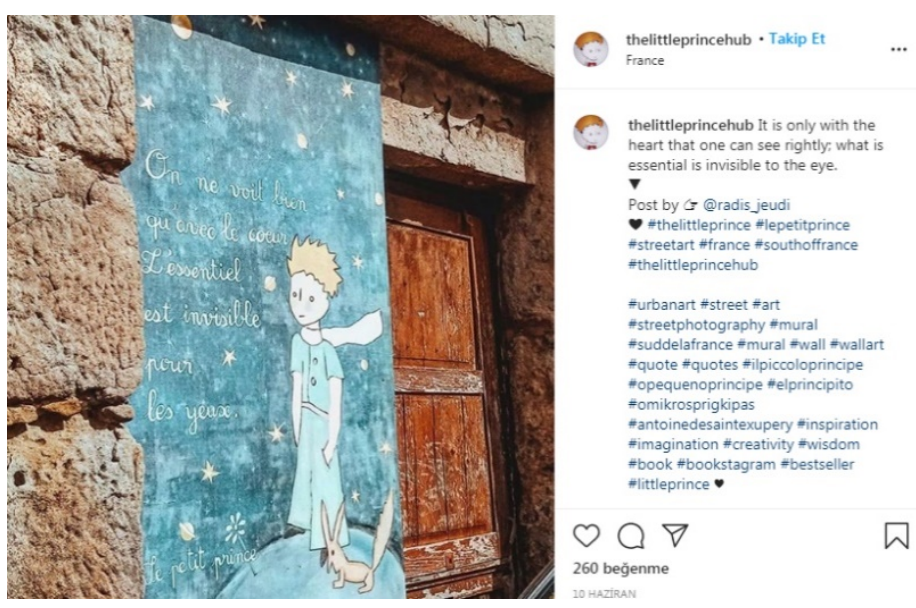

Tablo 4. 10.06.2020 Findings of the Interaction Rates of the Content of the Dated Post

\begin{tabular}{ll}
\hline Likes & 260 \\
\hline Interpretation & 2 \\
\hline Response to the content & 1 \\
\hline Content & It is only with the heart that one can see rightly; what is essential is invisible to the eye. \\
\hline Tag & \#thelittleprince, \#lepetitprince, \#streetart, \#france, \#southoffrance, \#thelittleprincehub, \\
\hline
\end{tabular}

Micro Structure: In the post dated June 10, there is a metaphorical saying in the statement, using the words out of their basic meaning. 'It is only with the heart that one can see rightly; What is essential is invisible to the eye. "This passive sentence cannot be evaluated according to the principle of causality.

Macro Structure: In the photo, the Little Prince and his friend fox are pictured on a wall. By referring to the novel, a positive language was used, with a quote of people who see it with their hearts. One of the two comments shared is the page manager's thank you reply. 
Example 5. 14.06.2020 Dated Post

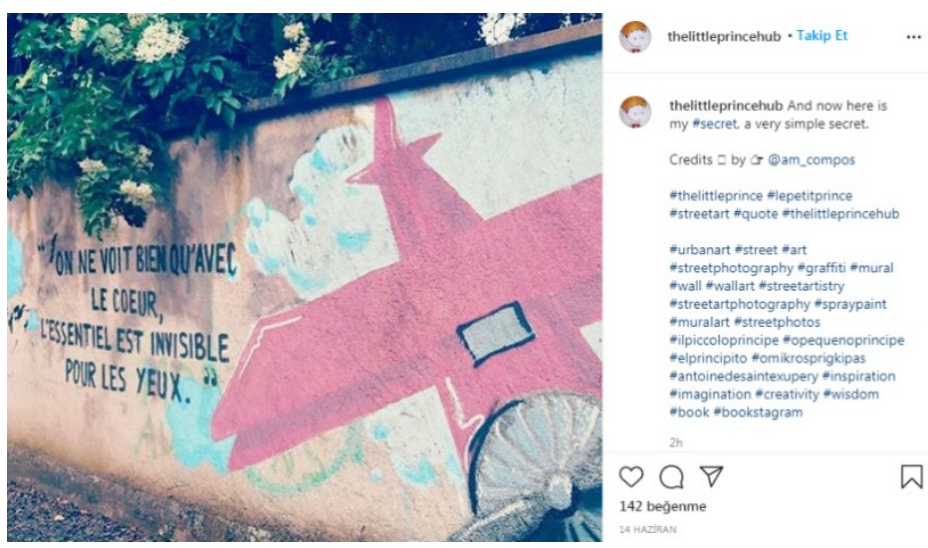

Table 5. 14.06.2020 Findings of the Interaction Rates of the Content of the Dated Post

\begin{tabular}{ll}
\hline Likes & 142 \\
\hline Interpretation & 1 \\
\hline Response to the content & 0 \\
\hline Content & And now here is my secret, a very simple secret. \\
\hline Tag & \#thelittleprince, \#lepetitprince, \#streetart, \#quote, \#thelittleprincehub, \\
\hline
\end{tabular}

Micro Structure: In the message dated June 14, the words were used in the basic sense and no metaphor finding was found. The sentence "And now here is my secret, a very simple secret."is simple and has no causal relationship since it is a single sentence.

Macro Structure: Reference is made to the pilot character in the novel with the plane depicted in the photo and the sentences next to it. A positive language is used with the quote of "And now here is my secret, a very simple secret" and no otherizing discourse is included. There is a comment on the sharing and the page manager has no answer.

\section{Example 6. 19.06.2020 Dated Post}
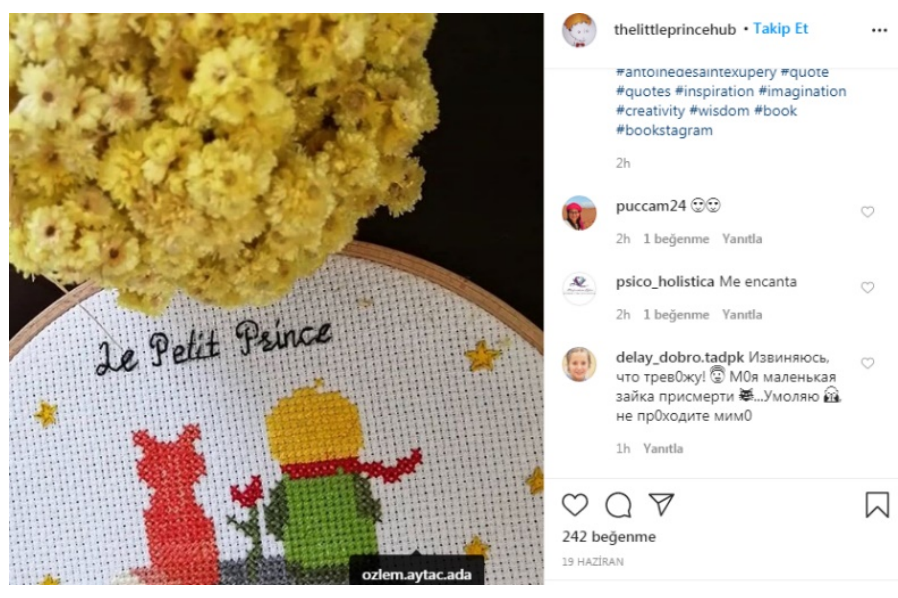

Table 6. 19.06.2020 Findings of the Interaction Rates of the Content of the Dated Post

\begin{tabular}{ll}
\hline Likes & 242 \\
\hline Interpretation & 3 \\
\hline Response to the content & 0 \\
\hline Content & It is the time you have wasted for you rose that makes your rose so important. \\
\hline Tag & \#thelittleprince, \#lepetitprince, \#crafts, \#embroidery, \#thelittleprincehub, \#needlework \\
\hline
\end{tabular}

Micro Structure: In the content shared on June 19, the words are used in a basic sense, and there is no use of metaphors. The repetition of the word rose shows that repetition art is used. Since simple structured sentence is a single sentence, evaluation cannot be made on causality relationship.

Macro Structure: Flower and handicraft embroidered Little Prince, rose and fox are depicted in this photograph, referring to the love expressions of the characters in the novel. A positive language was used 
with the quote: "It is the time you have wasted for you rose that makes your rose so important." No thanks were received from the page manager for the 3 comments shared.

Example 7. 21.06.2020 Dated Post

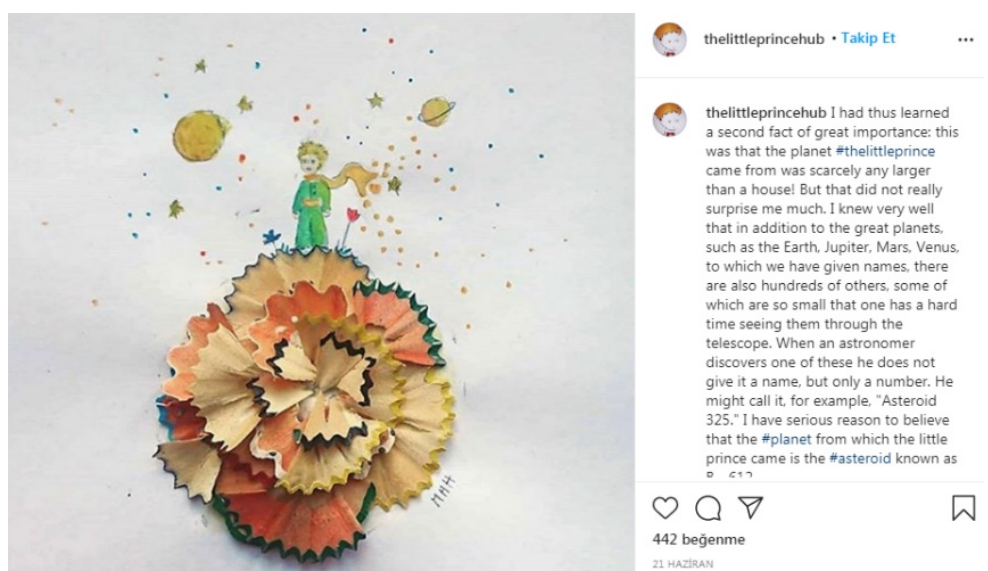

Table 7. 21.06.2020 Findings of the Interaction Rates of the Content of the Dated Post

\begin{tabular}{ll}
\hline Likes & 442 \\
\hline Interpretation & 12 \\
\hline Response to the content & 4 \\
\hline Content & I had thus learned a second fact of great importance: this was that the planet the little prince \\
& came from was scarcely any larger than a house! But that did not really surprise me much. I \\
& knew very well that in addition to the great panets, such as the Earth, Jupiter, Mars, Venus, to \\
& which we have given names, there are also hundreds of others, some of which are so small that \\
& one has a hard time seeing them through the telescope. When an astronomer discovers one of \\
& these he does not give it a name, but only a number. He might call it, for example, "Asteroid \\
& 325." I have serious reason to believe that the planet from which the little prince came is \\
& the asteroid known as B - 612. \\
\hline Tag & \#thelittleprince, \#lepetitprince, \#art, \#fanart, \#paint, \#thelittleprincehub, \#sketch \\
\hline
\end{tabular}

Micro Structure: In the message dated June 21, words are used literally and the use of metaphors is not included. There is causality between sentences in the sharing where the active sentence structure is dominant. It was emphasized that the size of the place that the person adopts as home does not matter. It is argued that the Little Prince's house has justifiable reasons to believe that it is "Asteroid B-612".

Macro Structure: A planet form has been created from pencil tip residues. On these leftovers, a small rose was drawn to the right of the prince, and a boap plant was drawn to the left. Pencil tip residues were used as metaphors with the form they created. A positive language has been used and there is no discriminative discourse. 4 of the 12 comments shared are the responses of the page manager. The page manager responds to comments on the content by emoji or thanks.

Example 8. 23.06.2020 Dated Post

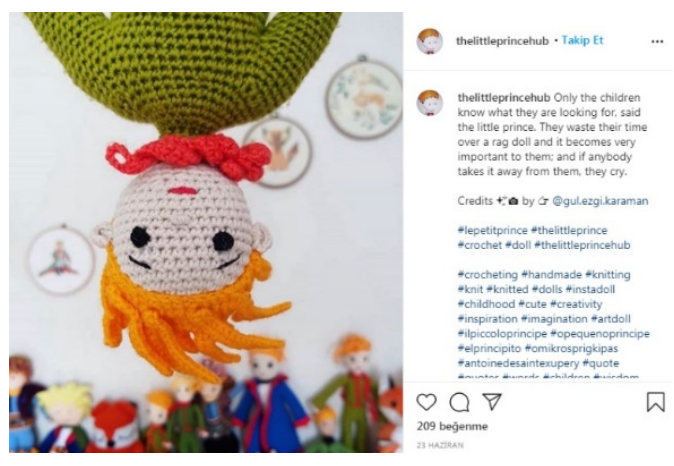


Table 8. 23.06.2020 Findings of the Interaction Rates of the Content of the Dated Post

\begin{tabular}{ll}
\hline Likes & 209 \\
\hline Interpretation & 5 \\
\hline Response to the content & 1 \\
\hline Content & $\begin{array}{l}\text { Only the children know what they are looking for, said the little prince. They waste their time over } \\
\text { a rag doll and it becomes very important to them; and if anybody takes it away from them, they } \\
\text { cry. }\end{array}$ \\
\hline Tag & \#thelittleprince, \#lepetitprince, \#doll, \#crochet, \#thelittleprincehub, \#handmade \\
\hline
\end{tabular}

Micro Structure: In the post dated June 23, the words are used in its basic sense and there is no metaphor. There is an active sentence structure. The causal link between the two sentences is based on love. If someone leaves what she/he likes, she/he gets upset, cries and it means that children know this.

Macro Structure: In the photo with dolls, the Little Prince character is included. Toys made of mesh are lined up in a row at the bottom of the wall and the photo of the leading character is taken upside down. In the quote, that children know what they want, and adults do not, but there is no negative discourse. There are 5 comments in the content. One of them is the answer of the page manager.

Example 9. 27.06.2020 Dated Post

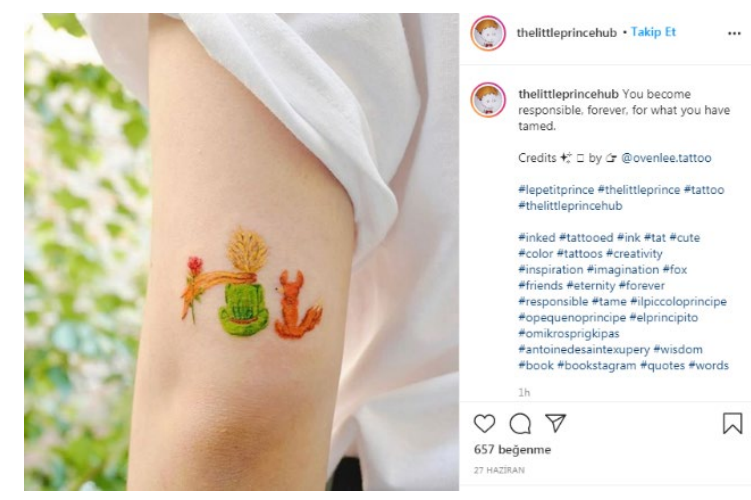

Table 9. 27.06.2020 Findings of the Interaction Rates of the Content of the Dated Post

\begin{tabular}{ll}
\hline Likes & 657 \\
\hline Interpretation & 10 \\
\hline Response to the content & 0 \\
\hline Content & You become responsible, forever, for what you have tamed. \\
\hline Tag & \#thelittleprince, \#lepetitprince, \#tattoo, \#inked, \#thelittleprincehub, \\
\hline
\end{tabular}

Micro Structure: In the message dated June 27, the words were used in their basic meaning and there was no meaning containing metaphor. In the quote of "You become responsible, forever, for what you have tamed.", There is a simple sentence usage with active structure. Causality is not sought because the sharing contains a single sentence.

Macro Structure: In the photo, there is a unique friendly fox on the right side of the little prince and a rose on the left side. A reference is made to the friends of the Little Prince with a quote you become responsible, forever, for what you have tamed. There is a positive use of language when the table is interpreted. There are 10 comments on sharing. The messages were not answered by the page manager.

Example 10. 28.06.2020 Dated Post

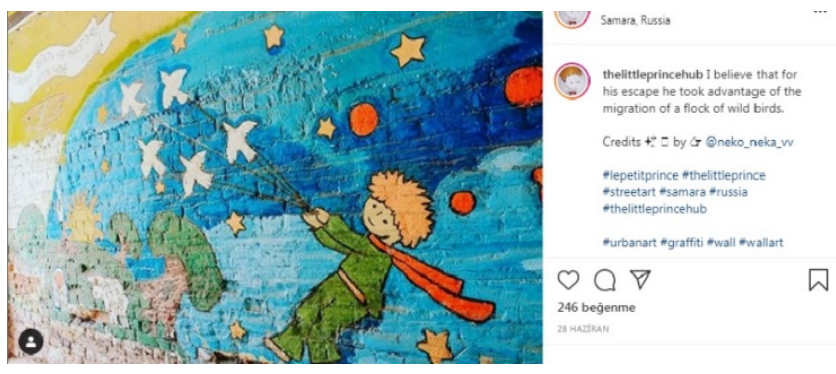


Table 10. 28.06.2020 Findings of the Interaction Rates of the Content of the Dated Post

\begin{tabular}{ll}
\hline Likes & 246 \\
\hline Interpretation & 2 \\
\hline Response to the content & 0 \\
\hline Content & I believe that for his escape he took advantage of the migration of a flock of wild birds \\
\hline Tag & \#thelittleprince, \#lepetitprince, \#tstreetart, \#samara, \#russia, \#thelittleprincehub, \\
\hline
\end{tabular}

Micro Structure: The words in the sentence were not used as its connotation and figurative meaning in the sharing of June 28. Only an sarcastic saying was used. There is a simple sentence structure with active structure. "I believe that for his escape he took advantage of the migration of a flock of wild birds" there is no causal relationship, since this quote consists of a single sentence.

Macro Structure: In the photo, we see the Little Prince and the stars around him, who are preparing to fly with flying birds. There is a positive use of language with the combination of quote and photo. Two comments on the content have not been answered by the page manager.

Example 11. 29.06.2020 Dated Post

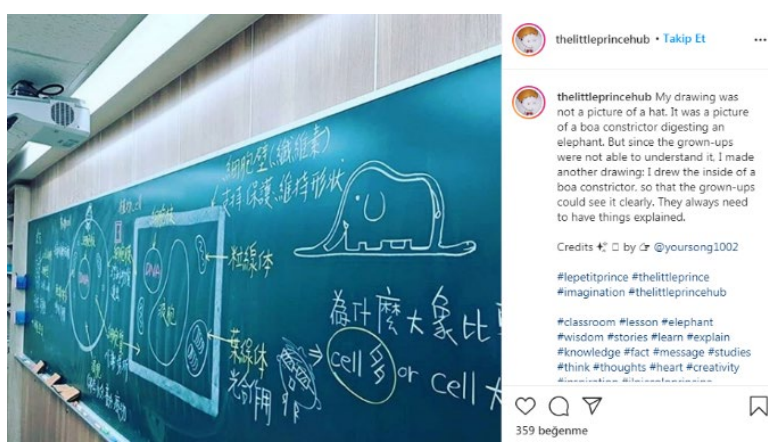

Table 11. 29.06.2020 Findings of the Interaction Rates of the Content of the Dated Post

\begin{tabular}{ll}
\hline Likes & 359 \\
\hline Interpretation & 7 \\
\hline Response to the content & 2 \\
\hline Content & My drawing was not a picture of a hat. It was a picture of a boa constrictor digesting an \\
& elephant. But since the grown-ups were not able to understand it, I made another drawing: I \\
& drew the inside of a boa constrictor, so that the grown-ups could see it clearly. They always need \\
& to have things explained \\
\hline Tag & \#thelittleprince, \#lepetitprince, \#imigination, \#classroom, \#lesson, \#thelittleprincehub, \\
\hline
\end{tabular}

Micro Structure: In the message dated June 29, the words were used in the basic sense. Metaphor use is not included. The sentences are active and simple. There is a causal relationship between sentences. As nobody could understand the message that the picture wanted to give, it was redrawed. Thus, it suggests that everyone will understand the meaning of the picture.

Macro Structure: The photo contains some calculations and drawings. A positive language is used with a combination of quotation and photography. There are 7 comments for sharing. The page manager was able to give her/his followers two answers.

\section{Conclusion and Discussion}

Thanks to its interactive infrastructure, Web 2.0 users in virtual networks as a cultural industry area; It provides easy access to culture, arts, entertainment and information. Within these social areas, changes occur while individuals construct their perceptions and identities. Attaining its virtual identity, the prosumer also creates its own style of discourse in alternative media.

Within this structure that digitizes artistic and cultural contents, individuals meet in a new virtual universe with pages that match their interests. This meeting and prosumer concept should be considered as the carrier column of the culture industry in a virtual environment. In the Instagram account opened in the name of the novel titled The Little Prince, how it served the spread of the culture industry was examined. The quotations and photos shared on the fan page titled The Little Prince Hub were generally shared by staying true to the content of the book. The findings obtained as a result of the 11 photographs 
examined are as follows: There is only one photo with the little prince book and this post is a picnic post. In the other 10 posts, there are posts with the image of the little prince in the book. In the photos there is a picture of the little prince depicted on the piece of skateboard. The posts also include a photograph of the road, the portrait of the little prince drawn on the door, and an airplane drawn on the wall. It is seen that hand-knitted babies are shared in addition to the sharing of the little prince, the fox and his flower handcrafted. It is noteworthy that the little prince's planet is shared with the remnants of the pencil and then his teachings are written on a classroom board.

Finally, it is intriguing that the hero of this book and his friends are loved enough to get a tattoo, and the tattoo is shared and displayed on social media.

In line with the discourse analysis of the Little Prince, which is both a novel character and a social media phenomenon, in the bookstagram account, two categories come to the fore in the posts: incomprehensibleness and love. The drawings of elephants and snakes, which remind the pilot character in the novel, were included in the incomprehensible content. In addition, the photographs containing the aircraft and calculations were brought to the appropriate form with a quote. These combinations, which reflect the inner world of the character, include complexity and imagination. Little Prince, his house and friends are in the foreground in love-themed sharing. These shares, which tell what the essence of love is in the language of the Little Prince, contain elements that contain labor. The use of vibrant colors in messages is remarkable.

As a result of the analysis of the quotes in the Little Prince book, it was concluded that a constructive language was used in positive sentence structures. Since the Little Prince is the wisest and loving child on the planet, it is possible to see his positive perspective in the sharings.

Apart from the content of the book, the Little Prince Hub page includes sharings. Fruit basket, skateboard, road photo, etc. As a bookstagram account, it is not encouraging the page to read the sharings in this content or introducing characters in the novel. For this reason, the functions of the page such as book promotion and reading are questioned by the reader.

The admin, identified with the Little Prince character, can message with followers. Admin even gives them advice from the digital world and thanks them for each likes and comment. Admin continues to show the daily life of the Little Prince and grow his virtual family.

\section{Ethical Declaration}

In the writing process of the study titled "The Little Prince in Bookstagram in the Context of the Culture Industry: From Asteroid B-612 to Social Media Planet", there were followed the scientific, ethical and the citation rules; was not made any falsification on the collected data and this study was not sent to any other academic media for evaluation. Since the document is examined in this study, there is no requirement for an ethics committee decision.

\section{References}

Adorno, T. W., \& Rabinbach, A. G. (1975). Culture industry reconsidered. New German Critique, (6), 12-19.

Adorno, T., \& Horkheimer, M. (2000). The culture industry: Enlightenment as mass deception (1944). Dialectic Of Enlightenment, 94-136.

Adorno, T. W., \& Adorno, T. W. (2001). The Culture Industry: Selected Essays On Mass Culture. Psychology Press.

Adorno, T. W. (2020). Kültür Endüstrisi Kültür Yönetimi,(Çev: N. Ülner, M.Tüzel,E.Gen).İstanbul: İletişimyayınlar1 Anık,C., Ve Soncu,A. (2011). Kültür, Medeniyet Ve Modernizm Üzerine “Yaprak Dökümü” Bağlamında Bir

Değerlendirme. Global Media Journal, 2, 52-83.

Assoun, Paul- Laurent (2014). Frankfurt Okulu (Çev: I. Ergüden). Ankara: Dost Kitabevi.

Ayaz, B. (2016). Geç Kapitalizm: Medya Ve Sanatta İçeriğin Metalaşması Ve Anlamsızlaşması. Abant Kültürel Arastırmalar Dergisi, 1(1), 119-128.

Bayram, Y. (2016). Yerelde Öteki Olmak: Suriyeli Sı̆̆ınmacıların Trabzon Yerel Gazetelerinde Söylemsel Temsili. Journal Of International Social Research, 9(42). 1416-1430

Berg, B. L., \& Lune, H. (2019). Sosyal Bilimlerde Nitel Arasttrma Yöntemleri. Konya: Eğitim Yayınevi.

Boratav, O., \& Gürdal, N. (2016). Kültür Endüstrisi Bağlamında Sanat Eserinin Tecimselleşmesi Ve Metanın Estetize Edilişi. Yuldı Journal Of Art And Design, 3(2), 96-109.

Bottomore, T. (2016). Frankfurt Okulu Ve Eleştirisi (Çev: Ü, H,. Yolsal), İstanbul: Say Yayınları.

Buzzetto-More, N. (2013,July). Social Media And Prosumerism. In Proceedings Of The Informing Science And Information Technology Education Conference (Pp. 67-80). Informing Science Institute.

Chul Han, B. (2019). Yorgunluk Toplumu (Çev: S. Yalçı) İstanbul: Açılım Kitap. 
Cook, D. (1996). The Culture Industry Revisited: Theodor W. Adorno On Mass Culture. London: Rowman \& Littlefield Publishers.

Dellaloğlu, B. F. (2018). Frankfurt Okulu'nda Sanat Ve Toplum. İstanbul: Say Yayıncilık.

Doğan, M. Z. (2015). Sosyal Medyada Kültür Endüstrisi Üretme Bağlamında Üre-Tüketicilik: Olric Hayran Sayfası Örneği1. Uluslararası Hakemli İletişim Ve Edebiyat Araștırmalar Dergisi,8. Doi: 10.17361/UHIVE.2015813156

Duman, K., Ve Özdoyran, G. (2018). Dijital Emek Ve Kullanıcı İçeriğinin Metalaşması: Katılımcı Sözlük Yazarlar1 Üzerine İnceleme. Erciyes İetişim Dergisi, 5(4), Https:/ / Doi.Org/10.17680/Erciyesiletisim.419811

Fairclough, N. (2013). Critical Discourse Analysis: The Critical Study Of Language. New York: Routledge.

Fenercioğlu, M., (2012). Theodor Adorno'nun Sanat Anlayışı Ve Johann Sebastian Bach İle İlgili Görüşleri. Konservatoryum Dergisi, Vol.2, 1-10

Filibeli, T. E. (2018). Kullanıcı Türevli İçerik Ve Yurttaş Medyası: Haberin Dönüşümü, Sınırlar Ve Olanaklar. Akdeniz Iletisim. 453-469. Https:/ / Doi.Org/10.31123/Akil.456219

Finlayson, J. G. (2014). Hegel, Adorno And The Origins Of Immanent Criticism. British Journal For The History Of Philosophy, 22(6), 1142-1166. Https://Doi.Org/10.1080/09608788.2014.993918

Finlayson, J. G. (2015). The Artwork And The Promesse Du Bonheur In Adorno. European Journal Of Philosophy, 23(3), 392-419. DOI: 10.1111/J.1468-0378.2012.00542.X

Grant, J. (2013). The End Of Critique? Ideology As Replication in Adorno and Jameson. Culture, Theory And Critique, 55(1), 1-16.Doi:10.1080/14735784.2012.762617

Güzel, M. (2006). Küreselleşme, İnternet Ve Gençlik Kültürü. Küresel İletişim Dergisi, 1(1), 1-16.

Guzel, E. (2016). Dijital Kültür Ve Çevrimiçi Sosyal Ağlarda Rekabetin Aktörü:“'Dijital Habitus. Gümüşhane Üniversitesi İletisism Fakültesi Elektronik Dergisi, 4(1). 82-103. Https:/ / Doi.Org/10.19145/Guifd.26114

Hellings, J. (2014). Messages In A Bottle As The Work Of Art. In Adorno And Art (Pp. 71-78). London: Palgrave Macmillan.

Jessop, S. (2016). Adorno: Cultural Education And Resistance. Studies in Philosophy And Education, 36(4), 409423. Http://Dx.Doi.Org/10.1007/S11217-016-9531-6

Kalkan, A., Ve Altınkurt, L. (2012). Günümüz Sanat Ortamında Çağdaş/Güncel Sanat Yaklaşımlarına İlişkin Sanatçı, Eleştirmen Ve Sanat Galericilerinin Görüşleri. Dumlupinar Üniversitesi Soysyal Bilimler Dergisi, (34) 125-136.

Keltie, E. (2017). The Culture Industry And Participatory Audiences. New York; London: Palgrave Macmillan.

Koluaçık, İhsan (2017). Eleştirel Teorisyenlerin Kültür Endüstrisi Kavramı Çerçevesinde Sanata Ve Sinemaya Yaklaşımları. Abant Kültürel Araştırmalar Dergisi. Sayı. 3, S. 135-156.

Lankauskaitè, V \& Liubinienè, V. (2018). A Shift From "Me" To "We" In Social Media. Digital Age In Semiotics \& Communication, 1(1), 51-61

Moore, R. (2012). Digital Reproducibility And The Culture Industry: Popular Music And The AdornoBenjamin Debate. Fast Capitalism, 9(1) 75-88. Doi:10.32855/Fcapital.201201.010

Nar, M. Ş. (2015). Küreselleşmenin Tüketim Kültürü Üzerindeki Etkisi: Teknoloji Tüketimi. Journal Of International Social Research, 8(37).941-954

Odabaş, U. K. (2018). Frankfurt Okulu Ya Da Eleştirel Teori Üzerine. Dört Öge, (14), 211-233.

Pauwels, M.-C. (2015), 'Work And Prosumerism: Collaborative Consumption In The United States', In O. Frayssé, And M. O’Neil (Eds), Digital Labour And Prosumer Capitalism , (Pp. 66-84). The US Matrix, London: Palgrave Macmillan.

Renkçi, T. (2014). Postmodernizmde Yeni Bir Oluşum: Durumsal Estetik. The Turkish Online Journal Of Design Art And Communication. 4(1), 61-68

Rey, P. J. (2012). Alienation, Exploitation, And Social Media. American Behavioral Scientist, 56(4), 399420.Doi:10.1177/0002764211429367

Rodríguez-Ferrándiz, R. (2013). Culture Industries In A Postindustrial Age: Entertainment, Leisure, Creativity, Design. Critical Studies In Media Communication, 31(4), 327-341.Doi:10.1080/15295036.2013.840388

Romero, C. S. (2011). New Media Art And A Contemporary Revision Of The Term 'Cultural Industry'of Theodor Adorno. International Journal Of Art, Culture And Design Technologies, 1(2), 1-13. DOI: $10.4018 /$ Ijacdt.2011070101

Romero, C. S. (2018). Culture Industry: A Contemporary Revision Of The Term Of Theodor Adorno. In M. Khosrow-Pour, Enhancing Art, Culture And Design With Thecnological İntegration (Pp. 1-24). Hershey, Pennsylvania: Information Resources Management Association.

Sandvig, C. (2015). The Social İndustry. Social Media+ Society, 1(1), 1-4 DOI: 10.1177/2056305115582047

Sawyer, R \& Chen. G.M. (2012). "The Impact Of Social Media On Intercultural Adaptation." Intercultural Communication Studies, 21( 2), 2012, Pp. 151-169

Scott, L., \& Celia, L. (2007). Global Culture Industry. Cambridge: Polity Press.

Sevim, B. A. (2010). Walter Benjamin'in Kavramlarıla Kültür Endüstrisi:" Aura"," Öykü Anlatıcısı" Ve" Flâneur.". Journal Of International Social Research, 3(11). 509-516

Solak, Ö. (2011). Küçük Ağa Romanının Eleştirel Söylem Analizi. Akademik Bakış Dergisi, 26, 1-14. 
Stone, A. (2014). Adorno, Hegel, And Dialectic. British Journal For The History Of Philosophy, 22(6), 11181141.Doi:10.1080/09608788.2014.952264

Swingewood, Alan (1996). Kitle Kültürü Efsanesi, (Çev: A, Kansu) Ankara: Bilim Ve Sanat Yayınları

Şahoğlu, C. T. (2019). Konum Tabanlı Mobil Oyunlarda Oyun Emeğinin Metalaşması Ve Hibrit Mekânın Toplumsal Üretimi. Moment Dergi, 6(1), 176-198. Https://Doi.Org/10.17572//Mj2019.1.176198

Ulinnuha, R. (2015). Critical Discourse Analysis: Theory And Method İn Social And Literary Framework. Indonesian Journal Of Applied Linguistics, 2(2), 262. Https://Doi.Org/10.17509/İjal.V2i2.170

Ümer, E. (2016). Adorno, Debord Ve Baudrillard'da Kültür Ve Sanat. Sanat Ve Tasarım Dergisi Https://Doi.Org/10.18603/Std.95869

Van Dijk, T. A. (1985). Handbook Of Discourse Analysis. (4 Vols).London: Academic Press.

Van Dijk, T.A. (1988). News Analysis: Case Studies Of İnternational And National News İn The Press. Hillsdale, NJ: L. Erlbaum

Van Dijk, T. A. (1995a). Aims Of Critical Discourse Analysis. Japanese Discourse, 1(1), 17-28.

Van Dijk, T. A. (1995b). On Macrostructures, Mental Models, And Other İnventions: A Brief Personal History Of The Kintsch-Van Dijk Theory. In C. A. Weaver, III, S. Mannes, \& C. R. Fletcher (Eds.), Discourse Comprehension: Essays İn Honor Of Walter Kintsch (Pp. 383-410). Hillsdale, NJ: Lawrence Erlbaum Associates, Inc

Van Dijck, J. (2013). The Culture Of Connectivity: A Critical History Of Social Media. New York: Oxford University Press.

Yıkmış, S. (2020). Türkiye Türkçesinde Empati Dili (Söylem Çözümlemesi).Dede Korkut Uluslararası Türk Dili Ve Edebiyat Arastırmalar Dergisi, 9(21), .39-62. Https:/ / Doi.Org/10.25068/Dedekorkut320

Yılmaz, N.Ç. (2018). Sanat Ve Kültür Endüstrisi Art And Culture Industry. Uluslararası Sosyal Araşttrmalar Dergisi,11(61) 452-459 Http://Dx.Doi.Org/10.17719/Jisr.2018.2935

Yurdigül, Y., Yurdigül, A., \& Batur, M. (2015). Frankfurt Okulu'nda Birey Ve Toplum: İnsanın Şeyleşmesi Ve Kültürün Metalaşması Üzerine Eleştirel Okumalar. Journal Of Graduate School Of Social Sciences, 19(2). 97-110

Zhang, L. (2017). Fashioning The Feminine Self In "Prosumer Capitalism": Women's Work And The Transnational Reselling Of Western Luxury Online. Journal Of Consumer Culture, 17(2), 184-204. DOI: $10.1177 / 1469540515572239$

\section{TÜRKÇE GENİŞ ÖZET}

Kültür endüstrisiyle yapay, sıradan ve imal edilmiş bir kültürün meydana geldiği söylenebilmektedir. Yüksek ve alt kültür çizgisi homojenleşmekte sanatın orijinalitesi, aurası ve özgürlügüne prangalar vurularak sanat metalaştırlmaktadır(Dellaloğlu, 2018, s. 112-123). Adorno'ya göre sanat, hayali bir evrenselliktir. Kültür endüstrisi, bu homojen alanın evrenselliğindedir; sanat mutluluk vaatlerinde bulunmayan ancak emekten vazgeçip kolayca eğlence sağlayabilendir (Adorno ve Adorno, 2001, s. 7).

Kültür endüstrisiyle piyasa için üretilmesi planlanan sanat eserleri metalaşmaktadır. Sanat eserlerinin gizili, özerkliği, kültür endüstrisi üreticileri eliyle kasıtlı ya da kasıtsız bir şekilde yok edilmeye meyillidir. Özerkliğin korunması, ekonomik gerekliliğin yerine getirilmesine bağlı olsa da, bu gerekliklerin karşılanması özerklik için yeterli bir koşul teşkil etmeyebilir (Cook, 1996, s. 113). Kültür endüstrisindeki bu metalaşma her sanat dalında olduğu gibi edebiyatta da kendisini gösterebilmektedir. 18.yüzyılln ilk çeyreğinde İngiltere'deki ekonomik kaygiyla yazılan romanlarda bu durum gözlenebilmektedir. Kültür endüstrisinde inovasyon olarak sunulan şeyin, aynı kostümün yeniymiş gibi giydirilmesinden ibaret olduğu söylenebilmektedir (Adorno, 2020, s. 111-112).

Kültür endüstrisi üretimi, sosyal medyanın hayatımıza girmesiyle bu mecralara transfer olup varlığını sürdürmektedir. Geniş bir kitle, sosyalleşmek amacıyla bu mecralarda buluşmakta; tanıdıklık hissiyle sosyalleşip yeni kimlikler inşa etmektedir. Yeni iletişim teknolojileriyle üretici ve tüketici kimliğini bütünleştiren çevrimiçi platformlarda içerik üretimine katılabilmektedir (Keltie, 2017, s. 1). Sosyal medyadaki üre-tüketiciler günden güne büyüyerek sosyal ve kültürel olarak toplanmak için araç olarak kullandıkları bu sanal ortamda soyut sermaye ile somut sonuçlar almaktadırlar (Rey, 2012, s. 415). Üretüketiciliğin, üreten ve tüketen kimlik ayrımını ortadan kaldırdığı söylenebilmektedir. Dijital olarak hareket eden bir üre-tüketici topluluğu, paylaşmak, takas etmek, kiralamak için internet üzerinden etkileşim kurabilmektedir (Pauwels, 2015, s. 66). Prosumerizm araştırmalarında beş farklı üre-tüketici grubu bulunmuştur: Faydacılar, Eğlencelikler, Avukatlar, Eş Yaratıcılar ve Rakipler (Buzzetto-More, 2013, s. 68).

"Boş zaman endüstrileri” veya "eğlence" terimlerinin kullanılmasıyla birlikte "yaratıcı endüstriler" ifadesinin de yayın bir şekilde kullanıldığını görmekteyiz. Bunun medyaya yakınsaması kültürel eğlence durumu olarak değerlendiren yapıt ve düşünsel yahut estetik bakımından yüksek bir aralıkta değildir. Boş zaman ve eğlence aktiviteleri olarak, daha az zarif veya talepkar olanların bile, kültürel deneyimler, zaman, mekân, ritüeller ve özelden bağımsız, sürekli taşınabilir, açıklı̆̆ kavuşturulmuş, kesinlikle rastgele bir zevk sunduğu söylenebilmektedir (Rodríguez-Ferrándiz, 2013, s. 333-336). Araştırma kapsamında edebi sanat 
ürünlerinin, yakın ilişki kurduğu diğer sanat dalları ile harmanlanması sonucunda oluşan çıktıların sosyal medya mecralarında boş zaman eğlencesi olarak değerlendirilmesi ele alınacaktır. "Küçük Prens" romanının İnstagram sayfalarındaki paylaşımları, araştırmanın inceleme konusunu oluşturmaktadır. Bu İnstagram paylaşımları yapıtı orijinal formundan çıkararak, yeni medya ortamlarında sanal kimlik oluşturmada faydalanılan bir ürüne evirdiği aynı zamanda eserin paylaşımı arttıkça ürünün bilinirliği, tanınırlı̆̆ artırdığı önermesi baz alınmıştır.

Sosyal medya araçlarından biri olan İnstagram'da Küçük Prens adına açlan yerli ve yabancı birçok hesap yer almaktadir. "Little Prince", "The Little Prince BB612", "Little Prince Lover88", " Little Prince World", "The Little Prince Journey", "The Little Prince Everywhere" ve "The Little Prince Hub" isimli fan sayfaları bulunmaktadır. Araştırma kapsamında söylem analizi için belirlenen hesap "The Little Prince Hub"dur. Hesabın seçilmesinde aktif paylaşım yapılması, yüksek takipçi sayısı ve Küçük Prens romanından alıntılara yer vermesi ve ilk açılan fan sayfaları arasında yer alması önem arz etmektedir. Analiz 1-30 Haziran 2020 tarihleri arasındaki 11 paylaşımı kapsamaktadır.

Araştırma Van Dijk'in eleştirel söylem analizi yöntemi ile yapılmıştır. Paylaşımlar makro ve mikro yapıya uygun olarak iki evrede incelenmiştir. Makro yapıda tematik ve şematik unsurların çözümlemesine; mikroda ise ikincil başlık olarak sözdizimsellik, nedensellik ilişkisiyle retorik analize yer verilmiştir (Van Dijk, 1995, s. 384-386).

Antoine de Saint-Exupéry'in kaleme aldığı Küçük Prens isimli romanı ve adına açılan İnstagram hesabında kültür endüstrisi yayllımına nasıl hizmet ettiğini incelenmiştir. The Little Prince Hub isimli fan sayfasında paylaşılan alıntılar ve fotoğraf kombinasyonu genel olarak kitabın içeriğine sadık kalınarak paylaşılmaktadır.

Hem bir roman karakteri hem de bir sosyal medya fenomeni olan Küçük Prens’in bookstagram hesabındaki söylem analizi doğrultusunda paylaşımlarda iki kategori ön plana çıkmaktadır: Anlaşılamamak ve sevgi. Anlaşılamamak içerikli paylaşımlarda romandaki pilot karakterini hatırlatan fil ve yılan çizimleri, uçak ve hesaplamaların yer aldığı fotoğraflar seçilerek alıntılla uygun forma getirilmiştir. Sevgi temalı paylaşımlarda Küçük Prens, onun evini ve dostlarını anlatan kareler ön plandadır. Analizi sonucunda basit, aktif, olumlu cümle yapılarında yapıcı bir dil kullanıldığı sonucuna ulaşılmıştır.

The Little Prince Hub sayfası iletilerinde kitap içeriği dışında paylaşımlara yer vermektedir. Bookstagram hesabı olarak sayfanın bu içerikteki paylaşımları okumaya teşvik edici veya romandaki karakterleri tanıtıcı değildir. Bu nedenle sayfanın kitap tanıtma, okumaya teşvik etme gibi işlevlerini okuyucuya sorgulatmaktadır. Küçük Prens karakteri ile özdeşleşen admin, takipçilerle mesajlaşmakta; onlara her bir beğeni ve yorum için teşekkür etmekte; ayrıca emojiyle sevgisini göstermektedir. 